\title{
Productive Zakat as a Fiscal Element for the Development and Empowerment of Micro Enterprises in East Java Province
}

\author{
Ana Toni Roby Candra Yudha and Nurul Lathifah \\ State Islamic University Sunan Ampel of Surabaya \\ Paper to be presented at International Conference of Zakat (ICONZ) 2018 \\ 15-16 November, Universitas Gadjah Mada, Yogyakarta, Indonesia
}

\begin{abstract}
Productive zakat is zakat whose purpose is for development and empowerment of poor-yetcapable mustahik. The purpose of this study is to understand, review and analyze the productive zakat as a fiscal instrument in reducing poverty level and transforming both economic and social life of mustahik. This research uses qualitative approach. Primary data is in the form of data of interview and observation; while secondary data is obtained from various literatures. This research also uses triangulation analysis from informants with similar background, including BAZ officers, mustahik, and zakat experts. The results show that productive zakat is not directly distributed to mustahik only, but through a program run by zakat institution partners. Partners are fully responsible for zakat funds provided by zakat agencies. Productive Zakah is proven to help reduce poverty and has a positive effect on reducing unemployment in East Java. So, it is clear that zakat is a very pro-poor fiscal instrument. This study includes the subject of productive zakat which has implications for some fundamental economic elements, such as micro, small, and medium enterprise (MSMEs), and poor. Therefore, in millennium era, zakat management becomes vital in collection, distribution, and supervision of zakat. Social media can be put as main "instrument" in supporting zakat institutions.
\end{abstract}

Keyword: productive zakat, empowerment, micro small and medium enterprise

\section{INTRODUCTION}

Zakat is an obligation of every individual who has fulfilled certain conditions to issue a portion of his property which is regulated according to the provisions of syara '. Zakat is the third pillar of Islam after syahadah and prayer, so it is an obligation for every Muslim whose wealth has reached a certain threshold. As the word of Allah SWT in the At-Taubah verse 103:

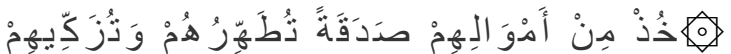

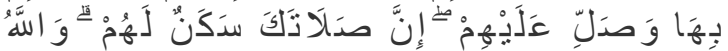

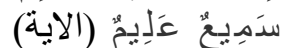

Take charity from a portion of their property, with that charity you cleanse and purify them, and pray for them. In fact your prayers (become) peace of mind for them. And Allah is Hearing, All-Knowing. (QS: At Taubah: 103)

And in Surah An-Nisa ayat 77:

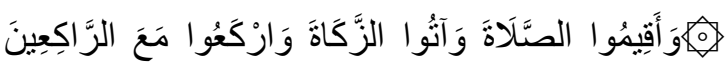

And establish prayer, give zakat and ruku 'along with those who are ruku' (QS: An Nisa': 77).

Zakat has a role in overcoming various economic problems because the management of good zakat will be a potential source of funds that can be used to advance the general welfare of the whole community. Zakat is given to 
mustahiq which is a group of people who are entitled to receive zakat. In accordance with the word of Allah SWT in Q.S. AtTaubah: 60:

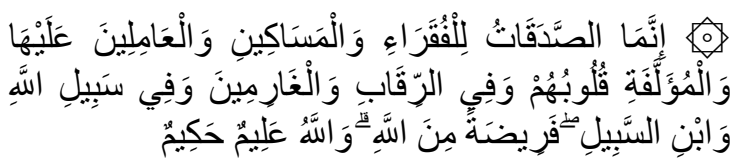

"Verily, the zakat is only distributed to the poor, the poor, the management of the zakat, the converts, freeing slaves. People owe, fi sabilillah and people who are on their way, as something that is obligatory for Allah. Verily Allah is Knower, Wise. "

But the high poverty rate has received attention from various circles, both government, private, and other community groups. The government has taken various ways to reduce the high poverty rate. Various strategic policies have been implemented through existing departments. The poverty alleviation program was carried out by opening as many jobs as possible, forming donor agencies that were ready at all times to collect and distribute aid from the community to those who lacked it.

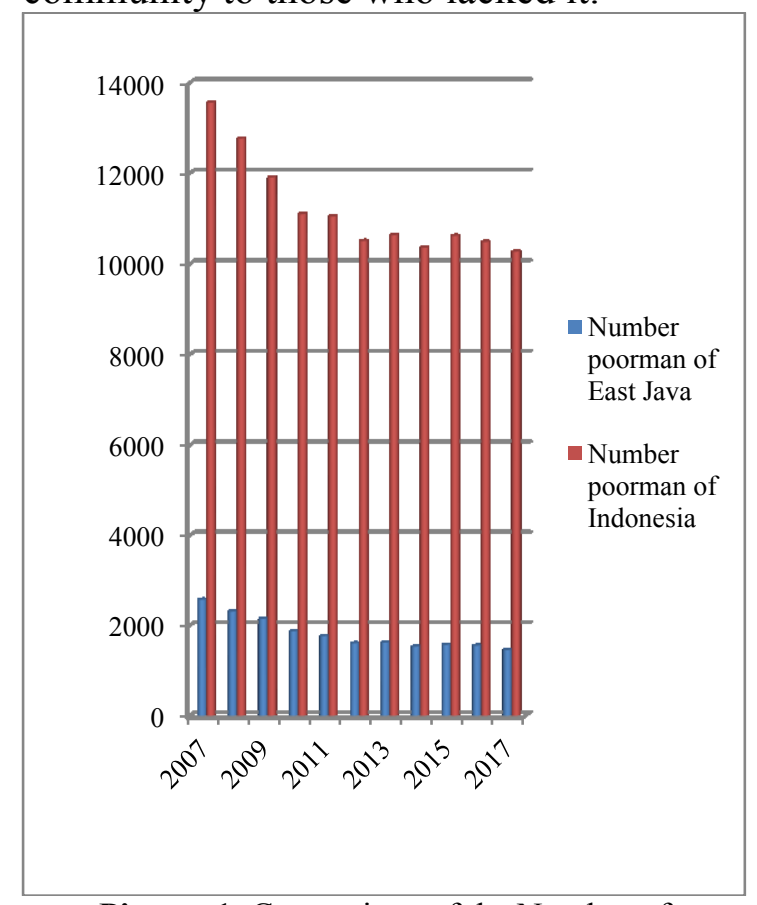

Picture 1. Comparison of the Number of Indonesian Poor Communities with East Java Province (thousands of lives) ${ }^{1}$
Referring to data from the East Java Central Statistics Agency (BPS) and National BPS, the number of poor families from year to year continues to decline. In 2007 to 2017 or for the past 10 years the number of poor people in both the provinces of East Java and Nationally decreased, whose values were 400 thousand and 2 million respectively. At first glance that number seems to have decreased from the previous year. Whereas in fact BPS only calculates the population that is categorized as poor and very poor. Whereas the poor category does not count. This problem is only a matter of poverty and unemployment. ${ }^{1}$

Meanwhile unemployment figures also showed very high numbers. Referring to the Central Statistics Agency (BPS) data in 2000, the number of unemployed reached 30 million. This figure did not experience much change, despite a downward trend, which was around 28.8 million unemployed in 2002, and in 2004 it was still around 28 million. $^{2}$

Thus, zakat becomes an economic system that must be implemented in an effort to empower the people's economy. The potential for zakat is large (because of the many Muslims) as an alternative movement for poverty alleviation. ${ }^{3}$ Zakat collected and distributed also needs to be seen from the tasharruf ratio, if the amount of zakat collected is the same as the amount distributed, then the performance of the zakat institution can be said to be very good. While the implementation is

\footnotetext{
1 Kementerian Agama RI Direktorat Jenderal Bimbingan Masyarakat Islam Diektorat Pemberdayaan Zakat, Panduan Pengembangan Usaha Bagi Mustahik. (Jakarta: Kemenag RI, 2015)

2 Institut Manajemen Zakat. Profil 7 Badan Amil Zakat Daerah Provinsi dan Kabupaten Potensial di Indonesia. (Ciputat: PT Mitra Cahaya Utama, 2006)

3 Kementerian Agama RI Direktorat Jenderal Bimbingan Masyarakat Islam Diektorat Pemberdayaan Zakat, Panduan Pengembangan Usaha Bagi Mustahik. (Jakarta: Kemenag RI, 2015),26
} 
the level or level of poverty is expected to decrease. The following are data on zakat collection and distribution in the 20152016 period.

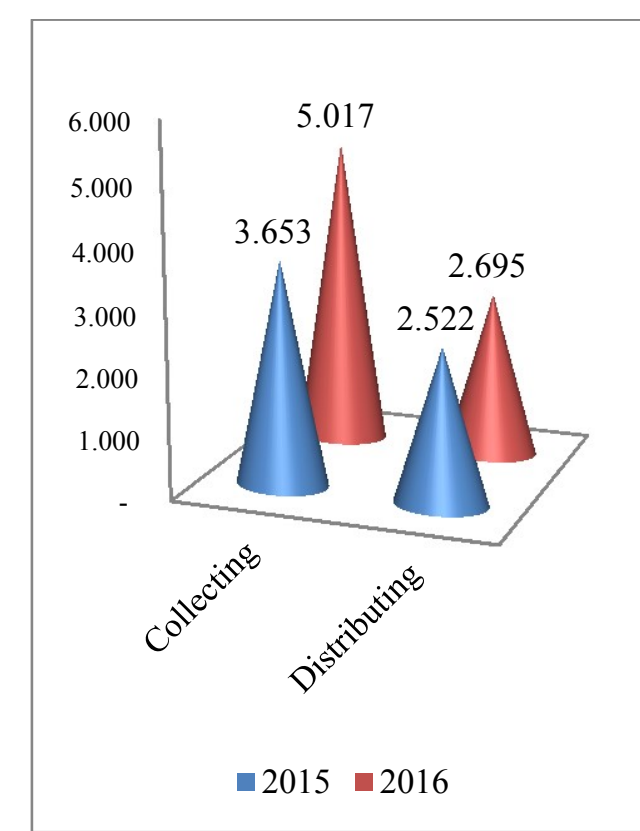

Picture2.Collection and Distribution of Zakat, Infaq, Alms and Other Religious Social Fund(in billion Rupiah) ${ }^{4}$

Referring to figure 2 it can be observed that the amount of zakat collected and distributed in 2015 and 2016 experienced an increasing trend. The average collection value increased by 20 percent in collection or by Rp. 1.4 trillion, but the distribution only increased by $\mathrm{Rp}$. 150 billion. The Tasharuf ratio in 2015 was $69.04 \%$, while in 2016 it was $53.17 \%$. On the basis of these ratios at least, zakat management related to transparency and accountability, still needs a lot of improvement and evaluation.

Good and equitable zakat management can overcome the problem of unemployment and poverty through the provision of working capital assistance. The same thing was stated in Law No. 23 of 2011 concerning Zakat Management which states that zakat management aims to realize community welfare and poverty alleviation. In addition, based on Law No. 38 of 1999 Article 5 paragraph 2 states

${ }^{4}$ Data zakat diolah dari berbagai sumber, 2018 that the purpose of zakat management is to realize social welfare and social justice. Even so, there are many problems that arise in various ways, whether it is from the few Muzakki who are aware of their obligations, or lack of professional zakat management institutions, or even zakat recipients who have not been able to manage the assistance received, so that even today Zakat has not able to be an alternative as a problem solving for social inequality.

If zakat management in Indonesia has been carried out in an organized manner, then the potential for zakat that can be extracted will be more optimal. The potential of Indonesian Muslims ranges from 83 percent of Indonesia's 230 million population. The figure of 83 percent of 230 million people means breaking the number of 190.9 million. News in Media Indonesia (2011) reports that the National Zakat Agency (BAZNAS) calls the potential for zakat that can be collected in Indonesia to reach Rp.217 trillion per year. However, currently only Rp1.5 trillion can be collected. While the potential zakat at the provincial level, West Java is the largest with a potential of 17.67 trillion. Followed by East Java 15.49 trillion and Central Java 13.28 trillion. $^{5}$

In order, zakat issued by someone to reach the target to the recipient who is entitled, it is necessary for an organization that specifically handles zakat, namely the Zakat Management Organization (OPZ). In Law No. 39 of 1999 Article 6, the management of zakat is carried out by the Zakat Agency (BAZ) formed by the government which consists of BAZ at the national, provincial, district / city, and subdistrict levels. BAZ at all levels has a coordinative, consultative and informative work relationship. In addition, in the Decree of the Minister of Religion of the

\footnotetext{
5 Media Indonesia, "Potensi Zakat Indonesia Mencapai 217 Triliun Per Tahun," 2011, http://www.mediaindonesia.com/read/2011/08/20/j 252447/293/14/Potensi-Zakat-di-Indonesia-Rp217Triliun-per-Tahun
} 
Republic of Indonesia No. 373 of 2003 article 1 is the Amil Zakat Institution (LAZ), which is also an OPZ, the zakat management institution that is formed by the community and confirmed by the government, and the Zakat Collection Unit (UPZ) which is an organizational unit formed by BAZ at all levels. According to the Indonesia Magnificence of Zakat (IMZ), as an institution that focuses on research, advocacy and capacity building on zakat management and public funds, it states that until now there has been at least the National Zakat Agency (BAZNAS) and 18 National Zakat Institutions (LAZ), 33 provincial level zakat institutions (BAZ), 429 district / city level BAZs, 4,771 district level BAZs, zakat collection units (UPZ), LAZ-LAZ regional level, to mosque and pesantrenbased traditional amil-amil. ${ }^{6}$ However, Mintarti in her article entitled "Efforts to Synergize Zakat in the World" said that: "The rapid growth of zakat management institutions is still not accompanied by efforts to strengthen organizational capacity, so capacity disparities are still quite high. This tendency has the potential to cause problems, especially related to the management of zakat and public trust. The public in general still see the performance of the Amil Zakat institution is not optimal. Most zakat management institutions have not been effective in collecting and distributing zakat. The culture of most zakat management organizations has not been oriented towards strengthening institutions and systems. In fact, this is absolutely necessary if the zakat management organization wants to take a significant role in handling the problem of poverty. ${ }^{7}$

\footnotetext{
${ }^{6}$ Nana Mintarti. "IMZ Award: Upaya Menuju Sinergi Zakat Dunia," 2011, http://imz.or.id/new/article/939/imz-award-upayamenuju-sinergi-zakat-dunia/

${ }^{7}$ Nana Mintarti. "IMZ Award: Upaya Menuju Sinergi Zakat Dunia," 2011, http://imz.or.id/new/article/939/imz-award-upayamenuju-sinergi-zakat-dunia/
}

A similar thing was expressed by Wajdi in his research on the differences in zakat management in Indonesia and Malaysia:

\begin{abstract}
"Technical management of zakat in Malaysia is carried out by PPZ (Center for Zakat Collection) in collecting zakat and Baitul Maal in its distribution under the State Islamic Religion Assembly. Because the PPZ has been in the form of a company, the management aspects of its zakat management funds are more advanced and well organized. The zakat management system in Malaysia has made use of sophisticated information and technology systems and also the database arrangement is good enough so that the population who become mustahiq and muzakki are well recorded, the number is right, and how much income is clear. In Indonesia, in accordance with article 12 the collection of zakat is carried out by Baznas by receiving or taking from muzakki. In addition, Baznas cooperates with banks in collecting zakat at the request of muzakki. In terms of utilization, Article 16 states that the results of the collection of zakat are utilized for the benefit of mustahiq in accordance with the provisions of religion based on priority scale, and can be used for productive businesses. The results of Indonesia's collection are less than Malaysia, this is due to the limited acceptance of zakat so that each institution will utilize it as creatively as possible. "8
\end{abstract}

In the management of zakat, an organization is needed that has the role of collecting and utilizing the collected zakat so that it is directed and focused on mustahiq and can develop. Therefore this is the task of Baznas in East Java. But how effective is the work program carried out by Baznas in East Java in empowering mustahiq economics.

\footnotetext{
8 Farid Wajdi, KajianPenerapan Zakat Sebagai Kredit Pajak dalam Pajak Penghasilan Orang Pribadi di Indonesia. (Jakarta: FISIP UI, 2008)
} 


\section{Problems}

Based on the background, the formulation of the problem in this study is how the performance of development and empowerment of MSMEs by zakat management institutions with productive zakat?

\section{Study Objectives}

The purpose of this study is to be able to know, study, analyze and produce implications related to the development and empowerment of MSMEs by using productive zakat.

\section{LITERATURE REVIEW}

\section{Mustahiq}

Mustahiq zakat is the person who has the right to receive zakat, and that refers to Surah at-Taubah [9] verse 60 . Meaning: "Indeed zakat is only for the poor, the poor, amil zakat, who is softened (convert), for (liberate) the slave, to (release) those who owe, for the way of Allah and for those who are in travel, as an obligation from God. Allah is AllKnowing, All-Wise. "From the above verse we know that the recipient of zakat consists of eight groups, namely: The poor, the poor, Amil zakat or people who manage zakat mal, those who are softened in their hearts (convert), To (liberate) the slave, To (liberate ) people who owe, For the way of Allah, and for people who are on their way. In its implementation, the division of the eight groups is carried out according to the amil zakat policy. Amil is permitted to share the zakat based on the circumstances of the local community.

Productive Zakat

Productive zakat for scientists as according to Darwan Raharjo is funds given to a group of people to be used as working capital. Zakat that is distributed to mustahiq for business purposes either to establish a business or to increase capital is zakat which is channeled productively. There are also other opinions which state that productive zakat is an adjective from the word production. This word will be clear in its meaning if it is combined together with the word it has. In this context the productive word is juxtaposed with the word zakat, so that it becomes productive zakat in which the use and use of zakat funds or the utilization of zakat are productive rather than the opposite, namely consumptive. ${ }^{9}$

Abdurrahamna Qadir also stated that the application of productive zakat has an impact on the realization of social justice, poverty alleviation and economic growth in the community. Abdurrahman Qadir also emphasized that the community or mustahiq who have received productive zakat in the form of business capital and training must also have added value. This is intended to improve the welfare of recipients of zakat from the poverty chain. $^{10}$

\section{Small, Medium Entreprise}

Definition of Small and Medium Enterprises as defined in PP no. 20 of 2008 are listed as follows:

\begin{tabular}{|l|l|l|c|}
\hline \multirow{2}{*}{$\begin{array}{c}\text { Business } \\
\text { Type }\end{array}$} & Net Worth & $\begin{array}{l}\text { Criteria } \\
\text { Total Sales } \\
\text { Annual }\end{array}$ & $\begin{array}{c}\text { Total } \\
\text { Labor }\end{array}$ \\
\hline Small & $\begin{array}{l}\text { more than } \\
\text { Rp 50 } \\
\text { milion up } \\
\text { to a max of } \\
\text { Rp 500 } \\
\text { milion not } \\
\text { including } \\
\text { land and } \\
\text { building }\end{array}$ & $\begin{array}{l}\text { 300 milion } \\
\text { to Rp 2,5 } \\
\text { billion } \\
\text { people }\end{array}$ & \\
& larger than & Rp 2,5 & \\
\hline Medium & & & \\
\hline
\end{tabular}

\footnotetext{
${ }^{9}$ Asnaini, Zakat Produktif dalam Prespektif Hukum Islam, (Yogyakarta: Pustaka Belajar, 2008),

10 Abdurrahaman Qadir, Zakat (Dalam Kondisi Mahdhah Dan Sosial), (Jakarta: PT Raja Grafindo, 2011), 163.
} 


\begin{tabular}{|l|l|l|l|}
\hline Rp 500 & billion to Rp & people \\
milion up & 50 milion & \\
to & \\
maximum & & \\
amount of & & \\
10 trilion , & & \\
not & & \\
including & & \\
land and & & \\
building & & \\
\hline
\end{tabular}

\section{RESEARCH METHODOLOGY}

The research methodology is discussed systematically in order, from research approach, data type and source, and data analysis technique. Here are the following.

\section{Type of Research}

According to the background, literature and research question, this research use qualitative approach, along with explorative case study strategy. This research is very much in need of researcher's involvement in deep investigation and check thoroughly individual behavior ${ }^{11}$.

Case study strategy enables to give access in explaining and analyzing social units, starting from small to bigger units. In this research, case study is focused to the pattern of zakat and other funds' empowerment which is addressed to productive elements and applied to workage and healthy mustahiq.

According to Moleong in Tika (2017:5), qualitative research is utilized to know and understand condition and phenomena occurred to research subject, such as behavior, perception, motivation, and other related issues.

\section{Type and Source of Data}

The needs of data in this research are comprised of primary and secondary data. Primary data is empirical data gained directly from source of information

${ }^{11}$ Tika and friends on Bungin, 2013, page 127 (informants). Primary data in this research is gained from informant through structured interview, observation, and documentation. Primary source of this research are the management and directors of zakat fundraiser (Lembaga Pengelola Zakat) with Badan Amil Zakat Daerah Jawa Timur (BAZDA Jatim) and LAZ Yatim Mandiri, as research object. As for the source of informants are zakat fundraiser, directors and distributors, as well as mustahiq and muzaki.

Secondary data in this research is gained through book archieves, journals, and documents related zakat distribution process, mustahiq's economic status transformation, basic needs completion, and economic self-reliant. Secondary data is from various literatures, including books and related journals.

\section{Data Analysis Technique}

Data analysis technique used is content analysis which focuses on literatures from institutions, both financial and philanthropy who involve in empowerment, as well as other proponent literatures.

The result of content analysis will be combined with the result of interview with Badan Amil Zakat Daerah Jawa Timur (BAZDA Jatim), national zakat fundraiser Yatim Mandiri, muzaki and mustahiq, as data confirmation and clarification to complete research, as well as synthesis from other empirical research to be elaborated for objective data.

\section{RESULT AND DISCUSSIONS}

In this sub-section, it is described regarding research result and discussion, including implementation of zakat productive, zakat and other social-religious fund to mustahiq, implication of productive zakat toward mustahiq's economic self-reliant (economic transformation). 


\section{Productive Zakat Implementation}

Reducing the level of poverty is an interesting discourse and become important subject in every country with Muslim majority community. The realization that zakat distributed only to capable-mustahiq, demands zakat fundraiser to create innovation program for new empowerment scheme.

The empowerment scheme applied by zakat fundraiser is undeniable that it has specialization.

There are some institutions focusing in those who are poor and fatherless; while some are focused in empowering by giving foods, and transforming a poor who is mustahiq (zakat recipient) to someone who capable, self-reliant, and eventually become a muzaki (zakat giver); other institutions who collected zakat from civil apparatus; as well as those who hold other specifications.

Productive zakat is distributed to mustahiq by zakat fundraiser with various empowerment programs, such as economic empowerment, education, health, and faith and piety improvement program.

\section{Distribution System of ZISKA to Mustahiq}

The distribution of zakat, infaq, and shadaqah, and other funds, particularly productive zakat to mustahiq, is given through various programs and policies from zakat fundraiser. BAZNAS, for example, is a fundraiser that owned by Indonesian government. They distribute productive zakat indirectly since 2012, yet they collaborate with other zakat manager unit (unit pengelola zakat-UPZ) as partner. UPZ was established at BAZNAS initiation and has teamed up with local government units (satuan kerja perangkat daerah-SKPD) under East Java provincial authority.

Distribution flow system of ZISKA can be made in a simple chart, as following:

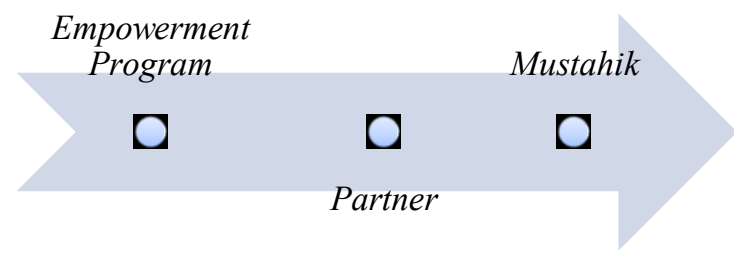

Figure 4. The Distribution Flow System of Zakat Productive of BAZNAS

Source: Primary data, proceeded

Zakat distribution in BAZNAS, generally can be illustrated with flowchart as illustrated in Figure 4. Managed zakat fund is formed in programs, mandated to partners and UPZ, then being distributed to mustahiq.

Zakat distribution in BAZNAS for empowerment that sourced from consumptive and productive zakat, is classified in 3 (three) clusters. For old/senior mustahiq that only live with their own, in an improper residence, they receive aid $\mathrm{Rp} 400.000$, and classified into "red" group. While, young mustahiq who is capable physically and mentally, receive guidance and supervision related to selfreliant and life-transformation.

The fact gained from BAZNAS financial report, the amount of ZISKA collected by BAZ is still dominated by zakat account, worth Rp. 393.251.480, with the smallest fund came from nonsyariah account, worth of Rp. 239.255. Total of ZIS collected Rp.795.875.954, while the distribution value amounted Rp.930.284.686, was calculated from its tasharruf ratio $117 \%$, which means that there is $17 \%$ of ZIS fund that excess. Furthermore, it can be understood that zakat fundraiser distribute $100 \%$ of fund, and even the excess fund that owned by the employee is being distributed to mustahiq.

ZISKA distribution done by zakat fundraiser from Lembaga Amil Zakat, generally is delivered directly with no third party involve, even if third party is needed, zakat fundraiser ask for help to mosque's takmir. The distribution of 
productive fund program can be illustrated as in flowchart in Figure 5.

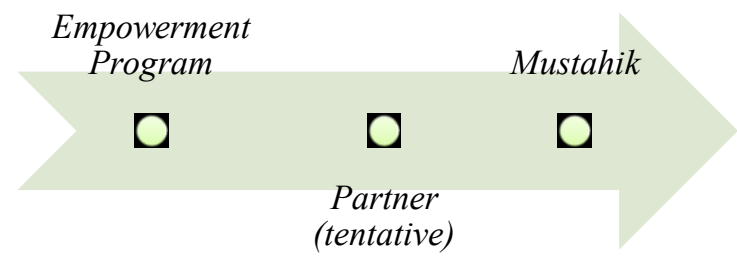

Figure 5. Productive Zakat Distribution System of LAZNAS

Source: Primary data 2018, processed

As illustrated in the figure above, the distribution is slightly different with the system applied by BAZNAS. The distribution system is similar, yet BAZNAS demand for partner to distribute productive zakat. Meanwhile, LAZNAS distribute directly to mustahiq. Partner is needed only in specific condition.

\section{Impelementation of Zakat Fundraiser Professionalism in Managing Zakat}

Zakat fundraiser has implemented several efforts to demonstrate the public that they are able maintaining the value and professionalism in their institution. The trust of muzaki and donors will become one of the conditions of its institution's existence, since zakat fundraiser will bear the trust of public if they want to show high professionalism and it is in line with its fund allocation. There are some variables applied to demonstrate whether zakat fundraiser has performed professionally. Those variables are implementation of supervision rights, policy concept, policy implementation, financial transparency, and audit.

According to data and information gathered, the result is shown as in the table below:

Table 1. Level of Professionalism of Zakat Fundraiser in East Java

\begin{tabular}{lcc}
\hline Assessment Variables & LAZNAS & $\begin{array}{c}\text { East Java } \\
\text { BAZNAS }\end{array}$ \\
\hline Supervision rights & $19 \%$ & $20 \%$ \\
Policy concept & $10 \%$ & $10 \%$ \\
\hline
\end{tabular}

\begin{tabular}{lll}
\hline Policy implementation & $35 \%$ & $35 \%$ \\
Financial & $15 \%$ & $15 \%$ \\
Transparency & & \\
Audit & $11 \%$ & $10 \%$ \\
\hline Total Value & $90 \%$ & $89 \%$ \\
\hline
\end{tabular}

Source: Primary Data 2018, processed

The assessment of performance of zakat fundraiser in general has received a very satisfying grade. The value index gained is almost $100 \%$. Each of the assessment, consecutively, LAZNAS got $90 \%$ of performance of value, while BAZNAS got $89 \%$. The value was an assessment that applied separately with in regular period.

i. Supervision rights

Board of supervision holds rights and authority given by the directors or managers to give and allocate its fund in zakat fundraiser. The purpose is for institution's development. Financial information and operational submitted in annual meeting is known by the supervisor, certainly with reliable accuracy of information, accuracy of delivery, and other non-financial information as indicators. Supervisor considered as founding father of zakat fundraiser hold advice rights to assign supervisor, assess supervisor and manager's performance, give suggestions in terms of compensation for supervisor and managers, as well as to select and assign external auditor.

ii. Policy Concept

Fundraiser has hold guidance that address in details regarding supervision rights, supervision tasks and regular job. In addition to that, fundraiser also has written guidance about disclosure, and ethical principle. Code of conduct is available for supervisor and for all employees in internal and external. Internal means that employees in its daily activities are part of the management; external means they 
are also part of field. The contents are ethical standard of employee toward mustahiq and muzaki, expectation of directors toward its managers and employees, and urgency of law compliance.

iii. Policy Implementation

Policy implementation in zakat fundraiser is considered to be effectively done. Zakat fundraiser also has internal policy toward BPH that possibly hold double position. This is possible if in BAZNAS level, they lack of human resources yet their coverage area is massive. Zakat fundraiser has divisions, such as audit division that serve for supervision and risk management. Others is zakat collection division that serve for collection zakat from muzaki and donors.

iv. Financial Transparency

Financial transparency is one of the vital indicators in assessing performance of institution. Zakat fundraiser provides financial report that also has been submitted to muzaki. The difference is that financial report for muzaki conveyed through monthly bulletin is general financial information; yet to auditor, detail financial report is required.

v. Audit

The quality of audit is taken from both internal and external audit assessment. Most of the assessment holds by BAZNAS and LAZNAS is satisfied with 'unqualified opinion'. Meanwhile, the assessment of financial performance gained from external auditor independently, has also in line with the increase of muzaki's trust toward the performance of zakat fundraiser.

\section{Implication of Productive Zakat Toward Mustahiq's Self-reliant}

Productive zakat, as discussed earlier, is zakat distributed only to mustahiq that physically and mentally capable. Therefore, the result of this research is indicated that there are several implications that expected to be policy recommendations. First, able to consider management, performance of zakat fundraiser, performance, and identify problem emerge from internal and external side of institution in collecting and distributing productive zakat. Second, various programs, work ethic, policy implementation, and professionalism implemented in zakat fundraiser, become a guidance to be conveyed to other zakat fundraiser in the efforts of completing distribution system and productive zakat management, to gain maximum benefits.

According to background, research question, research purposes, literature review, research method, as well as result and discussion, the researcher can conclude and several points of conclusion and suggestion as following:

\section{Conclusion}

There is several classification of mustahiq according to its economic capability, which are "red", "yellow", and "green" mustahiq. Others simply classify as "capable" and "incapable" mustahiq. Consumptive zakat is distributed to those in "red" line, which are those are incapable and are received zakat for the rest of their life. As for those who capable and healthy in physic and mental are classified in "yellow" and "green" line. They are trained and supervised to become selfreliant. Besides zakat, social fund is also distributed to mustahiq for empowerment program, taken from infaq and shadaqah.

Not only, collecting and distributing ZIS fund, zakat fundraiser also manage the fund by doing several innovations to develop the scale of empowerment program, therefore this can be called as "selling of program", arranging programs to be offered to muzaki and donors to help resolve problems regarding poor people (dhuafa). 
This is proven to be more interesting and gaining attention of muzaki to allocate their ZIS fund.

Empowerment done by zakat fundraiser to capable mustahiq is mostly addressed to make mustahiq self-reliant, capable and hold his own business. The development of quality and economic empowerment of mustahiq are part of mandate of UUD 1945, which stated "poor people and abandoned children must be cared by the state". The purpose of ZIS is clear, to empower mustahiq. Unlike tax that bears by all citizens regardless its level of economic, zakat is a pro-poor fiscal instrument.

\section{Suggestions}

Suggestion from this research is that productive zakat distributed by zakat fundraiser should be more productive and effective. Therefore, one should has alternative methods and innovations in collecting and distributing productive zakat to mustahiq to maximize empowerment.

1. MoU between BAZNAS and GoPay company give access for muzaki to spend his zakat. This is crucial since innovation is required in this era where people demand easiness, fast, accuracy, and transparency in collection and distribution productive zakat.

2. There must be a synergy between zakat fundraiser either BAZNAS or LAZNAS with other stakeholders in managing ZISKA funds. Synergy provides more space comparing to cooperation. BAZ and LAZNAS can mobilize UPZ massively to grow and develop that initiated by BAZNAS back in 2015 .

If zakat is considered to be crucial and effective as fiscal instrument, then innovation in management system Sistem Informasi Manajemen (SIMBA), and Nomor Pokok Wajib Zakat (NPWZ), and synergy between zakat fundraiser with online company is worth to be followed up, as well as the new regulation regarding the obligation of zakat managed and coordinated institutionally by zakat fundraiser, since the current regulation Zakat Act No.23 2011 only encourage public to do zakat in zakat fundraiser, not to encourage zakat fundraiser to collect zakat toward public.

\section{REFERENCES}

Asnaini .Zakat Produktif dalam Prespektif Hukum Islam.Yogyakarta: PustakaBelajar, 2008

Badan Pusat Statistik (BPS), 2017

Farid Wajdi, KajianPenerapan Zakat Sebagai Kredit Pajak dalam Pajak Penghasilan Orang Pribadi di Indonesia. (Jakarta: FISIP UI, 2008)

Institut Manajemen Zakat.2006.Profil 7 Badan Amil Zakat Daerah Provinsi dan Kabupaten Potensial di Indonesia.(Ciputat: PT Mitra Cahaya Utama,)

Kementerian Agama RI Direktorat Jenderal Bimbingan Masyarakat Islam Direktorat Pemberdayaan Zakat, 2015Panduan Pengembangan Usaha Bagi Mustahik. (Jakarta: Kemenag RI)

Qadir, Abdurrachman. Zakat (Dalam Dimensi Mahdah dan Sosial) Jakarta: RajaGrafindo Pesada, 2011.

Rahardjo, M. Dawan1999.Islam dan Transformasi Sosial Ekonomi, (Jakarta: Lembaga Studi Agama dan Filsafat)

Widiastuti, Tika, 2013,Pengaruh Kepatuhan Seorang Muslim Berzakat (Muzakki), Kinerja Lembaga Zakat di BAZ dan LAZ Terhadap Kesejahteraan Mustahiq. Surabaya: Program Pasca Sarjana Universitas Airlangga. Disertasi tidak dipublikasikan 
. 2016. Menakar Profesionalisime Nazhir Wakaf di Indonesia: Sebuah Studi Analisis Konten. Jurnal tidak terpublikasi

Yin, Robert K. L;2000. Studi Kasus: Desain dan Metode. Jakarta: PT. Raja Grafindo

Wawancara dengan Bendahara Umum Lembaga Amil Zakat Nasional (LAZNAS) Yatim Mandiri. Bapak Bagus Sembodo, 29 Agustus 2018

Wawancara dengan muzaki Lembaga Amil Zakat Nasional (LAZNAS) Yatim Mandiri. Bapak Sahid, 2 September 2018

Wawancara dengan Kepala Bidang Pengumpulan ZIS Badan Amil Zakat Nasional (BAZNAS) Propinsi Jawa Timur. Bapak Kholik, 2 September 2018

Wawancara dengan Kepala Bidang Pendistribusian ZIS Badan Amil Zakat Nasional (BAZNAS) Propinsi Jawa Timur. Bapak Candra, 22 Agustus 2018
Ana Toni Roby Candra Yudha

State Islamic University Sunan Ampel of Surabaya

Indonesia

Nurul Lathifah

State Islamic University Sunan Ampel of Surabaya

Indonesia 